NASA/TM-2005-213586

\title{
Solid Oxide Fuel Cell/Gas Turbine Hybrid Cycle Technology for Auxiliary Aerospace Power
}

Christopher J. Steffen, Jr., Joshua E. Freeh, and Louis M. Larosiliere Glenn Research Center, Cleveland, Ohio 
Since its founding, NASA has been dedicated to the advancement of aeronautics and space science. The NASA Scientific and Technical Information (STI) Program Office plays a key part in helping NASA maintain this important role.

The NASA STI Program Office is operated by Langley Research Center, the Lead Center for NASA's scientific and technical information. The NASA STI Program Office provides access to the NASA STI Database, the largest collection of aeronautical and space science STI in the world. The Program Office is also NASA's institutional mechanism for disseminating the results of its research and development activities. These results are published by NASA in the NASA STI Report Series, which includes the following report types:

- $\quad$ TECHNICAL PUBLICATION. Reports of completed research or a major significant phase of research that present the results of NASA programs and include extensive data or theoretical analysis. Includes compilations of significant scientific and technical data and information deemed to be of continuing reference value. NASA's counterpart of peerreviewed formal professional papers but has less stringent limitations on manuscript length and extent of graphic presentations.

- TECHNICAL MEMORANDUM. Scientific and technical findings that are preliminary or of specialized interest, e.g., quick release reports, working papers, and bibliographies that contain minimal annotation. Does not contain extensive analysis.

- CONTRACTOR REPORT. Scientific and technical findings by NASA-sponsored contractors and grantees.
- CONFERENCE PUBLICATION. Collected papers from scientific and technical conferences, symposia, seminars, or other meetings sponsored or cosponsored by NASA.

- SPECIAL PUBLICATION. Scientific, technical, or historical information from NASA programs, projects, and missions, often concerned with subjects having substantial public interest.

- TECHNICAL TRANSLATION. Englishlanguage translations of foreign scientific and technical material pertinent to NASA's mission.

Specialized services that complement the STI Program Office's diverse offerings include creating custom thesauri, building customized databases, organizing and publishing research results ... even providing videos.

For more information about the NASA STI Program Office, see the following:

- Access the NASA STI Program Home Page at http://www.sti.nasa.gov

- E-mail your question via the Internet to help@sti.nasa.gov

- Fax your question to the NASA Access Help Desk at 301-621-0134

- Telephone the NASA Access Help Desk at 301-621-0390

- Write to:

NASA Access Help Desk

NASA Center for AeroSpace Information 7121 Standard Drive

Hanover, MD 21076 
NASA/TM-2005-213586

\section{Solid Oxide Fuel Cell/Gas Turbine Hybrid Cycle Technology for Auxiliary Aerospace Power}

Christopher J. Steffen, Jr., Joshua E. Freeh, and Louis M. Larosiliere Glenn Research Center, Cleveland, Ohio

Prepared for the

Turbo Expo 2005

sponsored by the American Society of Mechanical Engineers

Reno, Nevada, June 6-9, 2005

National Aeronautics and

Space Administration

Glenn Research Center 


\section{Acknowledgments}

We would like to acknowledge the assistance of several individuals that helped to develop our understanding of the SOFC/GT hybrid system performance at the component level: Mr. Thomas Tomsik, Dr. Chia (Judy) Yen, Mr. Robert Tacina, Dr. Stephen Sofie, Mr. Thomas Cable, Dr. Jacob Brouwer,

Dr. Joseph Hartvigsen, and Mr. Jeffrey Berton.

This report contains preliminary

findings, subject to revision as analysis proceeds.

This work was sponsored by the Low Emissions Alternative

Power Project of the Vehicle Systems Program at the NASA Glenn Research Center.

Available from

NASA Center for Aerospace Information 7121 Standard Drive

Hanover, MD 21076
National Technical Information Service 5285 Port Royal Road Springfield, VA 22100 


\title{
Solid Oxide Fuel Cell/Gas Turbine Hybrid Cycle Technology For Auxiliary Aerospace Power
}

\author{
Christopher J. Steffen, Jr., Joshua E. Freeh, and Louis M. Larosiliere \\ National Aeronautics and Space Administration \\ Glenn Research Center \\ Cleveland, Ohio 44135
}

\begin{abstract}
A notional $440 \mathrm{~kW}$ auxiliary power unit has been developed for 300 passenger commercial transport aircraft in 2015AD. A hybrid engine using solid-oxide fuel cell stacks and a gas turbine bottoming cycle has been considered. Steady-state performance analysis during cruise operation has been presented. Trades between performance efficiency and system mass were conducted with system specific energy as the discriminator. Fuel cell performance was examined with an area specific resistance. The ratio of fuel cell versus turbine power was explored through variable fuel utilization. Area specific resistance, fuel utilization, and mission length had interacting effects upon system specific energy. During cruise operation, the simple cycle fuel cell/gas turbine hybrid was not able to outperform current turbine-driven generators for system specific energy, despite a significant improvement in system efficiency. This was due in part to the increased mass of the hybrid engine, and the increased water flow required for on-board fuel reformation. Two planar, anode-supported cell design concepts were considered. Designs that seek to minimize the metallic interconnect layer mass were seen to have a large effect upon the system mass estimates.
\end{abstract}

\section{Introduction}

NASA has a mission to help understand and protect the planet. As a result, the agency has devoted significant resources toward the goal of cleaner aerospace powerplants. One approach incorporates fuel cell power, which can be cleaner than combustion derived power. Nitrogen oxides $\left(\mathrm{NO}_{\mathrm{x}}\right)$, known environmental and health hazards, are virtually eliminated with fuel cell power systems because the requisite high temperatures are avoided altogether. If the fuel cell system efficiencies offer an improvement over combustion-based system efficiencies, then a reduction in $\mathrm{CO}_{2}$ emissions may result as well.

Some of the highest power system efficiencies reported to date have been associated with hybrid configurations combining high temperature fuel cell technology with conventional gas turbine technology [1]. The efficiency appears to scale with system power and offers an efficiency advantage over pure fuel cell systems even as small as the $500 \mathrm{~kW}$ scale. Siemens-Westinghouse has reported a 53 percent overall efficiency in the first-ever Solid Oxide Fuel Cell (SOFC) gas turbine hybrid system demonstration on a $\sim 200 \mathrm{~kW}$ system [2]. This 200 to $500 \mathrm{~kW}$ power range overlaps with the in-flight auxiliary power needs for conventional transport aircraft like the Boeing 777 [4].

Auxiliary power for commercial transport aircraft, derived from a high temperature fuel cell/gas turbine hybrid cycle engine, has received considerable attention over the last two years $[3,4,5]$. Aerospace auxiliary power is a promising application of SOFC technology for several reasons. The trend towards a more electric aircraft has been acknowledged within the aircraft industry. This trend is a direct outcome of the increasing electrical power requirements of modern transport aircraft. These increasing requirements should be met with an auxiliary system capable of delivering efficient electrical power during both cruise and ground operations. Currently, the propulsion engines are utilized for electrical power loads during the cruise operation. According to Daggett et al [5], this turbine engine/generator combination is 40 to 45 percent efficient at converting jet fuel to electrical energy during cruise operations. However, a separate gas turbine auxiliary power unit (APU) is used for electrical power primarily during ground operations. The current APUs is approximately 15 percent efficient [5] during the operating cycle. Shifting towards a fulltime duty APU with solid oxide fuel cell/gas turbine hybrid (SOFC/GT) technology promises a substantial improvement in system efficiency and overall $\mathrm{NO}_{\mathrm{x}}$ emissions. For the purposes of this paper, the mission analysis will involve cruise conditions only; therefore the 40 to 45 percent efficient figure will be used for comparison purposes.

Most hybrid SOFC/GT applications reported in the literature have been developed for ground power [1]. Therefore, systems are often configured to minimize cost of electricity (COE). In contrast, system power density (power/volume) and system specific power (power/mass) are paramount for aerospace systems. Consequently, we believe that aerospace system designs will look considerably different from ground power systems. There is also evidence that component designs, including the SOFC, should be different from the ground-based counterparts for these same reasons.

We have analyzed a baseline notional configuration that delivers $440 \mathrm{~kW}$ of auxiliary power at the cruise design point for a commercial transport aircraft. The technical assumptions behind the SOFC/GT performance are addressed herein. Our technical assessment was based upon steady-state performance analysis of the SOFC stacks, turbomachinery, and balance of plant (BOP) components. 
Mass and volume estimates for the various BOP components have been included, and a detailed presentation of component design and performance was included in a companion paper [6]. System sensitivities have been presented to quantify the effects of changing various system specifications. The figure of merit for these comparisons was system specific energy (i.e., energy delivered per-unit-mass of the engine system and required fluids.)

\section{Nomenclature}

$\begin{array}{ll}\text { NOx } & \text { Oxides of Nitrogen } \\ \text { SOFC } & \text { Solid Oxide Fuel Cell } \\ \text { SOFC/GT } & \text { SOFC with a Gas Turbine bottoming cycle } \\ \text { APU } & \text { Auxiliary power unit } \\ \text { COE } & \text { Cost of electricity } \\ \text { BOP } & \text { Balance of plant components } \\ \text { LHV } & \text { Lower heating value of the fuel stream } \\ \text { CPOX } & \begin{array}{l}\text { Catalytic partial oxidation process for fuel } \\ \text { reformation }\end{array} \\ \text { SECA } & \begin{array}{l}\text { Solid-state Energy Conversion Alliance, a } \\ \text { U. S. Department of Energy Program }\end{array} \\ \mathrm{m}_{\text {fuel }} & \text { Massflow of the fuel } \\ \mathrm{m}_{\text {H2O }} & \text { Massflow of the water } \\ \mathrm{A} & \text { Turbine flowpath annular area } \\ \mathrm{N} & \text { Rotational speed (rev. per minute) } \\ \text { E } & \text { System Specific Energy }(\mathrm{kW}-\mathrm{h} / \mathrm{kg})\end{array}$

\section{Baseline System Configuration}

Our analysis has been conducted upon the baseline configuration depicted below in figure 1. Aspen Plus V12.1 software was used to conduct the steady-state system simulations. Several key assumptions have shaped this system. The most significant assumption involved our presumed technology horizon of the year 2015AD. This demands that we credibly project component performance beyond a level demonstrated with present day systems. This assumption has guided the SOFC performance specification.

The total power output at cruise condition has been set at $440 \mathrm{~kW}$. The source of air during cruise operation has been specified as cabin air; therefore, we have fixed 75,153 $\mathrm{Pa}$ and $20{ }^{\circ} \mathrm{C}$ air inlet conditions. The cruise condition occurs at an altitude of 12,496 m (41 kft). We considered both short and long duration cruise mission profiles for comparing performance against a conventional APU. We have restricted our analysis to planar SOFC technology (versus tubular SOFC technology) due to the projected increase in stack specific power projected for large scale power systems [7].

Our fuel source was jet fuel. Jet-A has a relatively broad array of potential chemical constituents and as a result, a twelve-component assay was used as a surrogate for Jet-A. Figure 2 compares our distillation curve to that of other

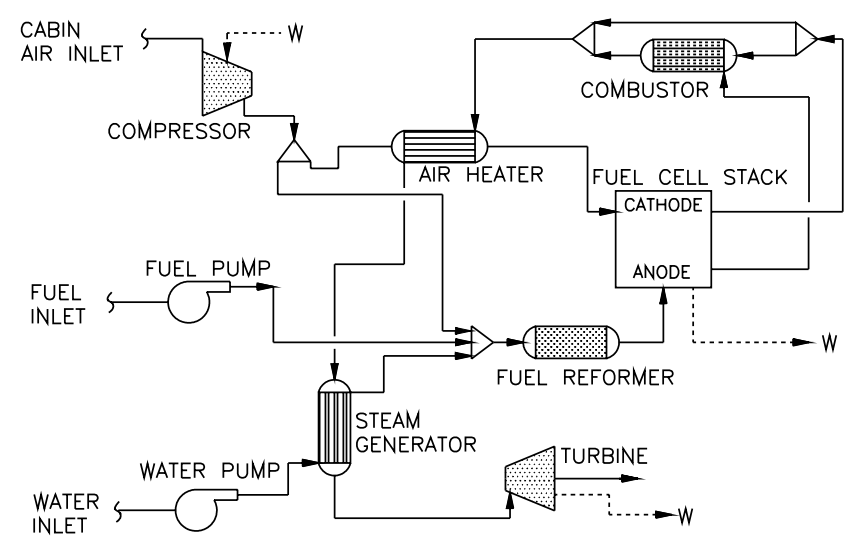

Figure 1.-Baseline SOFC/GT hybrid system configuration for $440 \mathrm{~kW}$ total power.

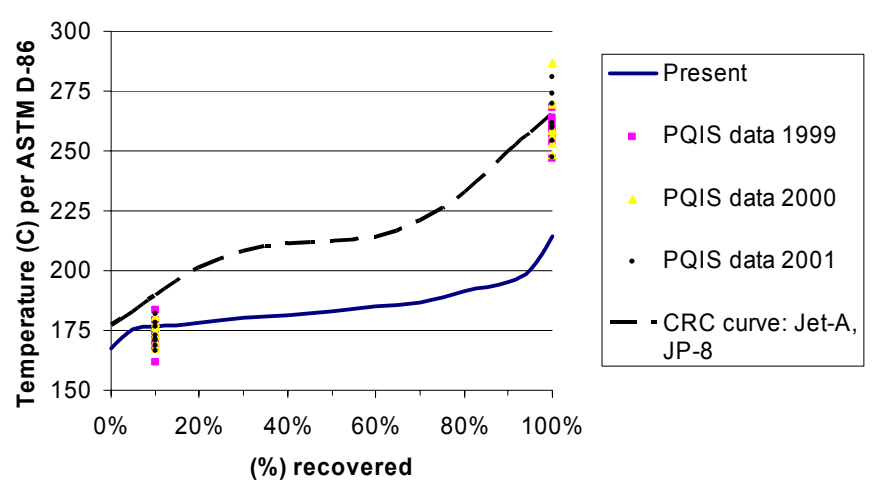

Figure 2.- Jet fuel properties; ASTM D-86 distillation curve compared to reference data [8-11].

available reference data $[8,9,10,11]$. Based on this assay, the average molecular formula was $\mathrm{C}_{10.329} \mathrm{H}_{21.516}$ and the calculated lower heating value (LHV) was $42,846 \mathrm{~kJ} / \mathrm{kg}$. All efficiencies specified have been computed using this LHV. The fuel reformation approach was based on catalytic partial oxidation (CPOX) chemistry, although some water is required to avoid coking. The reformer is operated at a molar atomic oxygen-to-carbon ratio of 0.95 and a molar steam-tocarbon ratio of 0.7 . The reformer operates in an exothermic fashion and a small amount of cooling is required to achieve SOFC stack entry conditions. Note that equilibrium chemistry is used throughout the system model.

Another major assumption that underpins our analysis involved the influence of sulfur compounds upon fuel reformation and energy conversion. We have omitted a desulfurizer component from our fuel processor. This omission implies one or more of the following developments over the next decade: (1) significant progress in sulfur tolerant catalyst development, (2) reduction of the sulfur content within the aviation fuel supply, or (3) off-board desulfurization and separate tankage for auxiliary power fuel. Currently, sulfur tolerant catalyst development is an 
active research area for the United States Department of Energy [1]. Projecting the sulfur content in aviation fuel over the next decade is hindered by considerable uncertainty. A complex interplay of changing federal fuel specifications (diesel and potentially jet fuel) and the economics of petroleum refinery operations clouds the issue [12]. Although a reduction in sulfur content of Jet-A can be reasonably expected over the next decade, it is by no means assured. Furthermore, it seems highly unlikely that the sulfur content will be reduced to levels that permit current catalyst technologies to operate on untreated jet fuel. ${ }^{\S}$ The validity of omitting a desulfurizer component should be monitored over the next decade in light of the issues highlighted above.

The BOP components operated with an assumed 2 percent pressure drop, except for the combustor that was modeled at constant pressure. The SOFC stacks were assumed to encounter a 1.5 percent pressure drop. All components were assumed adiabatic. The preheated air heat exchanger was consistent with compact plate-fin designs and a counterflow multipass steam generator was used to provide the steam for the reformer.

The baseline system has been specified to operate with a SOFC fuel utilization of 85 percent. This required a combustor to complete the reaction of the remaining 15 percent fuel content within the anode effluent. The combustor has been designed to accommodate near stoichiometric fuel-to-air ratio. The majority of cathode flow is routed around the combustor to avoid the extremely lean equivalence ratios that would otherwise result. A mixer combines the excess cathode flow and combustor effluent and routes these hot gases toward the gas-gas air heat exchanger, the steam generator and finally the radial turbine component before exiting the system.

\section{Solid Oxide Fuel Cell Model}

The SOFC performance model was based primarily upon the work of Hartvigsen et al [13]. The approach assumes an iso-thermal reaction of reformed hydrocarbon fuels. A standalone version of the Hartvigsen model was coded in Visual Basic and dynamically linked to the system simulation software. Thermochemical equilibrium analysis was performed with the NASA chemical equilibrium code [14] linked to the stand-alone model. Note that this was a singlepass thermodynamic cycle; anode and cathode recycling options were beyond the scope of the present work.

The Hartvigsen model was based upon an analysis of the Nernst potential and an assumed area specific resistance (ASR). The ASR represented all of the losses associated within the SOFC stack. The Nernst potential was an average value that captured the effect of fuel depletion within the anode gas channels. The average Nernst potential was

${ }^{8}$ The sulfur tolerance of current SOFC anodes (cermet of yttrium stabilized zirconia and nickel) is 50ppb at $750^{\circ} \mathrm{C}$ [1]; ASTM specification for Jet A is 0.3 percent by weight, while the average sulfur content of delivered jet fuel is closer to 0.03 percent [12].

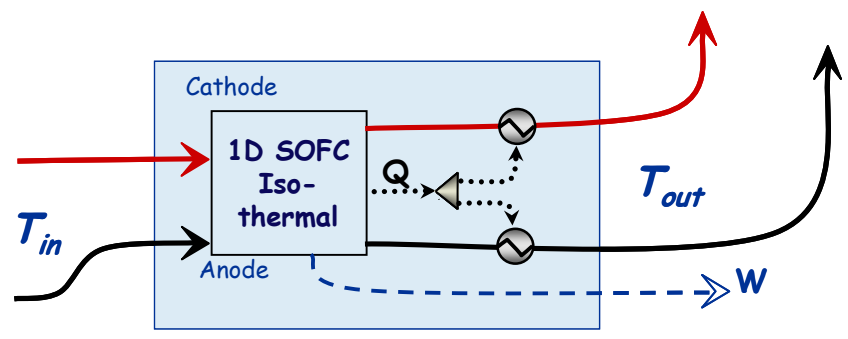

Figure 3.-SOFC stack cooling flow model; heat generated during stack operation is directed towards the anode and cathode effluent streams at a single exit temperature.

( $\mathrm{Q}$ is net heat transfer and $\mathrm{W}$ is net work).

calculated with a simple numerical routine instead of the direct analytical approach of [13]. This modification was required because the original model was developed for situations with a fully steam-reformed methane fuel stream. Thus, the allowable anode gas was restricted to a mixture of water, hydrogen, carbon monoxide, and carbon dioxide. However, our partial oxidation reformation at $973 \mathrm{~K}$ introduced significant concentrations of inert nitrogen (40 percent) and methane ( 1.5 percent $)$ in the reformate stream.

We have assumed that the SOFC operated as an adiabatic reactor with cooling provided through excess cathode flow. In order to account for this cooling flow, the heat generated during isothermal operation was directed to the anode and cathode effluent streams, as shown in figure 3. This simplification enabled a first order analysis of the cooling flows required. However, this simplification overlooks important temperature-dependant effects within the cell. The temperature dependence of ASR is well known, and of great significance to stack performance. For the present work, ASR should be interpreted as stack-averaged values.

The model has been configured to work with the following input data: stack ASR, operating voltage, pressure, isothermal temperature, reactant flow rates and utilization. The output data include product flow rates, required SOFC active area and current density. The remaining performance data can be calculated from these results. For the analysis that follows, the SOFC stacks operated at an ASR of $0.4 \mathrm{ohm}-\mathrm{cm}^{2}$, temperature of $973 \mathrm{~K}$, pressure of $208 \mathrm{kPa}$, and voltage of $0.75 \mathrm{~V}$ per cell.

Our technology horizon of 2015 led to the following important assumptions regarding cell construction:

\section{$1.20 \mathrm{~cm} \times 20 \mathrm{~cm}$ cells are achievable}

2. 175 cell stacks are achievable

3. $150 \mathrm{~K}$ temperature gradient across cell is achievable

4. Sealing technology can operate at pressure
$(\Delta \mathrm{p}=200 \mathrm{kPa})$


The former two assumptions reflect improvements in the SOFC stack specific power. The latter two assumptions reflect progress in thermal management of the SOFC stacks at operating conditions. Following the design requirements discussed in reference [15], a balance must be struck between controlling the thermal expansion mismatch within the cell, and the desire to achieve the "highest possible temperature gradient across [the] stack." The opposing goals of cell reliability and performance are at play here, and solutions tend to be design specific. We readily acknowledge that these assumptions, taken together, are beyond the current state of the art. They reflect our attempt at projecting stack performance out into the timeframe of interest.

\section{Turbomachinery Design and Analysis}

Baseline compressor and turbine designs are estimated from the thermodynamic cycle data using NASA-developed turbomachinery preliminary design and analysis tools [16]. A radial, single-shaft design was chosen, although a twoshaft system was considered due to its performance implications discussed below. Traditionally, the best configuration for nearly constant power output is a singleshaft configuration commonly used in APUs, marine applications, and some turboprop aircraft propulsion. The simplicity of the single-shaft configuration yields the lowest system part count and lowest system mass and cost. However, a double-shaft configuration allows for a larger overall pressure ratio across the expansion system. A double-shaft configuration exhibits lower design-point efficiency than the comparable single-shaft configuration due to added bearing and transition duct losses. Finally, operation of a single-shaft configuration in constant-speed mode usually provides superior transient response to load demands.

The single-stage radial turbine was limited to a maximum expansion ratio of approximately $6: 1$ primarily due to rotational stresses at the design condition. This can be seen in figure 4 , where $\left(\mathrm{AN}^{2}\right)$ and adiabatic efficiency are plotted as a function of expansion ratio. $\left(\mathrm{AN}^{2}\right)$ is a common turbine parameter that is proportional to specific strength, or rotational stress divided by density, and is typically kept below $6 \times 10^{10} \mathrm{in}^{2-} \mathrm{RPM}^{2}$. This limitation affected the entire system pressure profile because the optimum system design should expand the turbine exhaust to just above ambient pressure and thus maximize the turbine work output. After accounting for pressure losses throughout the system, the resulting compressor design total-total pressure ratio was 2.88:1 and the inlet pressure of the fuel cell was just over two bar. The seemingly low operating pressure of the fuel cell did not capture much of the well-documented pressure benefit [1]; maximizing turbine work appeared to outweigh any SOFC benefit.

The centrifugal compressor stage was designed as a backswept impeller discharging into a scroll via a row of vane diffusers. The compressor discharge temperature was predicted to be $144{ }^{\circ} \mathrm{C}$ and thus a stainless steel impeller was used. The radial turbine, comprised of an inlet volute, a row of nozzle vanes, a radial rotor and downstream exhaust duct, had a predicted inlet temperature of $417{ }^{\circ} \mathrm{C}$. This temperature is well below the current technology uncooled inlet temperature limit of about $880^{\circ} \mathrm{C}$, implying a relatively simple turbine design with conventional materials. Turbine life may also be extended due to the relatively low inlet temperature.

A compressor total-total polytropic efficiency of 86.0 percent and a corresponding adiabatic efficiency of 83.8 percent were used for the design point operation. The turbine total-total adiabatic efficiency was 91.2 percent. However, for this analysis, the corresponding total-static efficiency, 85.9 percent, was used to account for the energy lost due to the unrecoverable portion (swirl) of the flow.

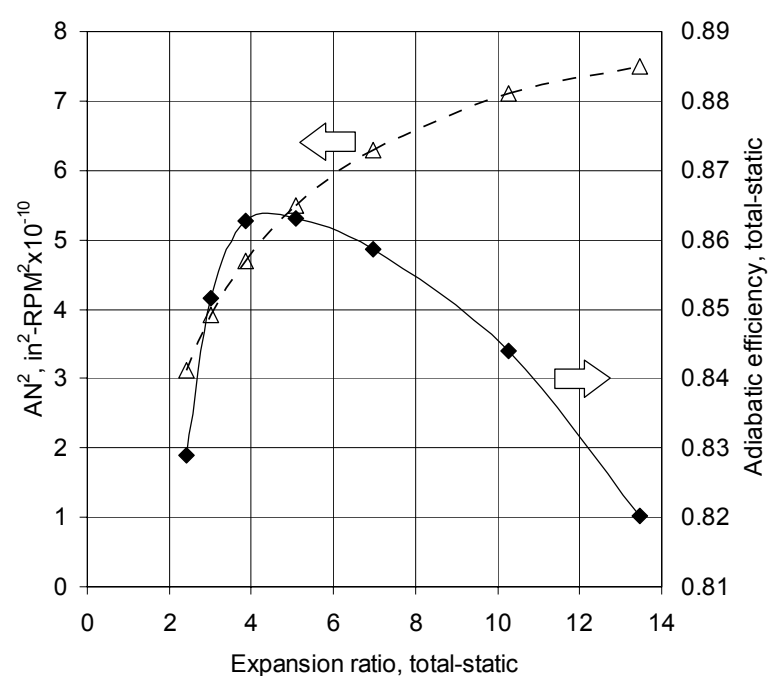

Figure 4.-Plot showing $\mathrm{AN}^{2}$ and adiabatic efficiency as a function of turbine design expansion ratio for the radial turbine.

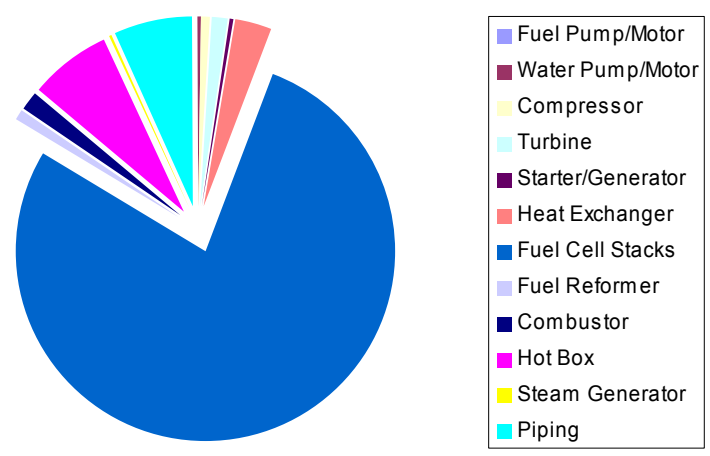

Figure 5.-SOFC/GT hybrid power APU system: mass breakdown by component. The total system mass is $1396 \mathrm{~kg}$. 


\section{Baseline System Performance}

Together, figure 1 and table 1 show the specification and performance of the baseline configuration. The system efficiency was 62.6 percent, based upon the jet fuel LHV. The corresponding mass breakdown is shown in the pie chart of figure 5. Clearly, the twelve fuel cell stacks dominated the estimate at 78 percent of the total system mass. A solid model of the configuration, shown in figure 6 , has been developed to fit within the tailcone section appropriate to a 300-passenger commercial transport jet. For comparison purposes, the Honeywell turbine APU (model 331 to 500) presently installed on Boeing's 777 aircraft is rated at $969 \mathrm{~kW}$ at sea level and weighs $331 \mathrm{~kg}$.

Further examination of the mass estimate reveals that the metallic interconnect represented the majority of the stack mass. Figures 5 and 7 indicate that progress towards significant mass reduction for this hybrid system should be directed towards the metallic interconnect component. This result was a direct outcome of the assumed cell mass model.

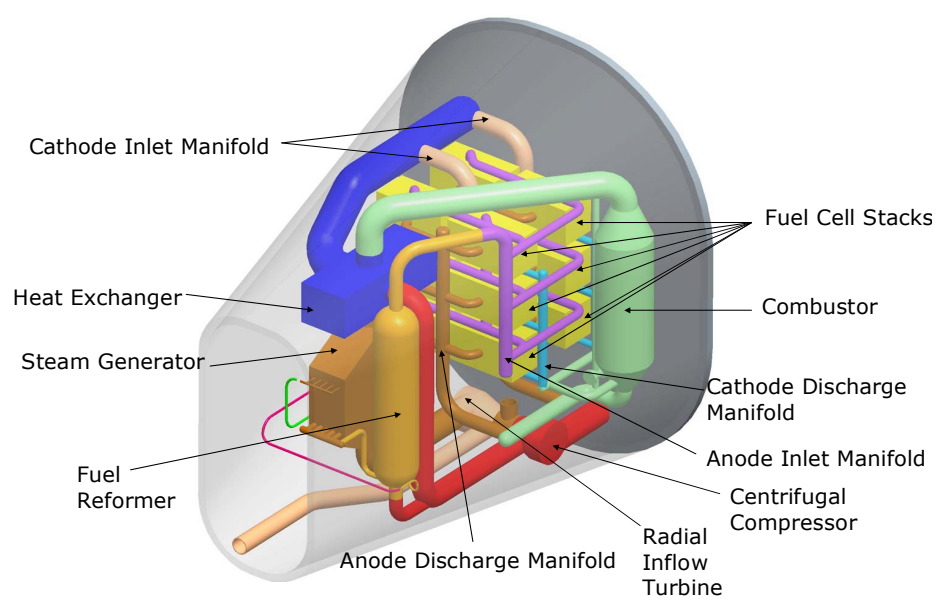

Figure 6.- Solid model of the APU baseline configuration, shown within the tail conestructure of a 300-passenger commercial jet aircraft.

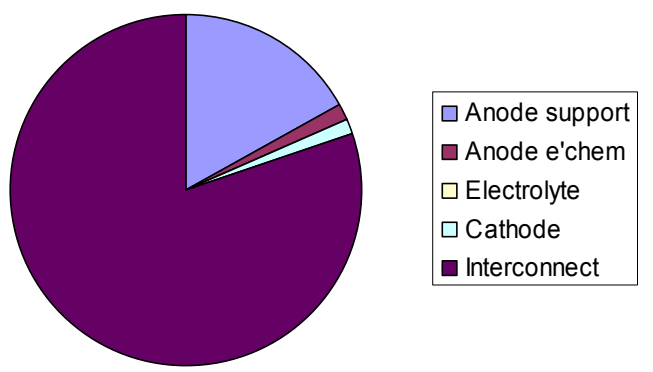

Figure 7.- - Repeating unit mass breakdown for the Planar Anode-supported SOFC cell with gas channels machined from a metallic interconnect (total $502 \mathrm{~g}$ ).

System
\begin{tabular}{|r|c|}
\hline SOFC net electrical power & $289 \mathrm{~kW}$ \\
\hline Generator net electrical power & $151 \mathrm{~kW}$ \\
\hline Total net electrical power & $440 \mathrm{~kW}$ \\
\hline Fuel flow (Jet-A) & $0.0164 \mathrm{~kg} / \mathrm{s}$ \\
\hline Water flow & $0.0148 \mathrm{~kg} / \mathrm{s}$ \\
\hline Air flow & $1.199 \mathrm{~kg} / \mathrm{s}$ \\
\hline System thermal efficiency (LHV) & $62.0 \%$ \\
\hline Air preheater heat duty & $677.8 \mathrm{~kW}$ \\
\hline Steam generator heat duty & $42.2 \mathrm{~kW}$ \\
\hline
\end{tabular}

\section{SOFC}

\begin{tabular}{|r|c|}
\hline Active Area per cell & $324 \mathrm{~cm}^{2}$ \\
\hline Average Nernst voltage & $0.980 \mathrm{~V}$ \\
\hline Cell voltage & $0.747 \mathrm{~V}$ \\
\hline Number of cells per stack & 170 \\
\hline Number of stacks & 12 \\
\hline Stack voltage & $127 \mathrm{~V}$ \\
\hline Current density & $583 \mathrm{~mA} / \mathrm{cm}^{2}$ \\
\hline Power density & $1.072 \mathrm{~kW} / \mathrm{L}$ \\
\hline Inlet temperature & $700 \mathrm{C}$ \\
\hline Exit temperature & $850 \mathrm{C}$ \\
\hline Inlet pressure & $2.08 \mathrm{bar}$ \\
\hline Exit pressure & $2.05 \mathrm{bar}$ \\
\hline Specific power & $0.266 \mathrm{~kW} / \mathrm{kg}$ \\
\hline Anode utilization & $85.0 \%$ \\
\hline Cathode utilization & $18.8 \%$ \\
\hline
\end{tabular}

\section{Reformer}

\begin{tabular}{|r|c|}
\hline H2O/C ratio & 0.70 \\
\hline O/C ratio & 0.95 \\
\hline Exit Temperature & $700 \mathrm{C}$ \\
\hline Inlet pressure & $2.01 \mathrm{bar}$ \\
\hline Exit pressure & $1.95 \mathrm{bar}$ \\
\hline Reactor Exotherm & $12.7 \mathrm{~kW}$ \\
\hline
\end{tabular}

Compressor

\begin{tabular}{|r|c|}
\hline Pressure ratio (total-total) & 2.88 \\
\hline Inlet temperature & $20 \mathrm{C}$ \\
\hline Exit temperature & $144 \mathrm{C}$ \\
\hline Adiabatic efficiency (total-total) & $83.8 \%$ \\
\hline
\end{tabular}

Catalytic combustor

\begin{tabular}{|r|c|}
\hline Inlet temperature & $850 \mathrm{C}$ \\
\hline Exit temperature & $1177 \mathrm{C}$ \\
\hline Estimated eq. ratio & 1.02 \\
\hline Inlet pressure & $2.05 \mathrm{bar}$ \\
\hline Exit pressure & $2.05 \mathrm{bar}$ \\
\hline
\end{tabular}

Turbine

\begin{tabular}{|r|c|}
\hline Expansion ratio (total-total) & 6.00 \\
\hline Inlet temperature & $417 \mathrm{C}$ \\
\hline Exit temperature & $191 \mathrm{C}$ \\
\hline Adiabatic efficiency (total-static) & $85.9 \%$ \\
\hline
\end{tabular}




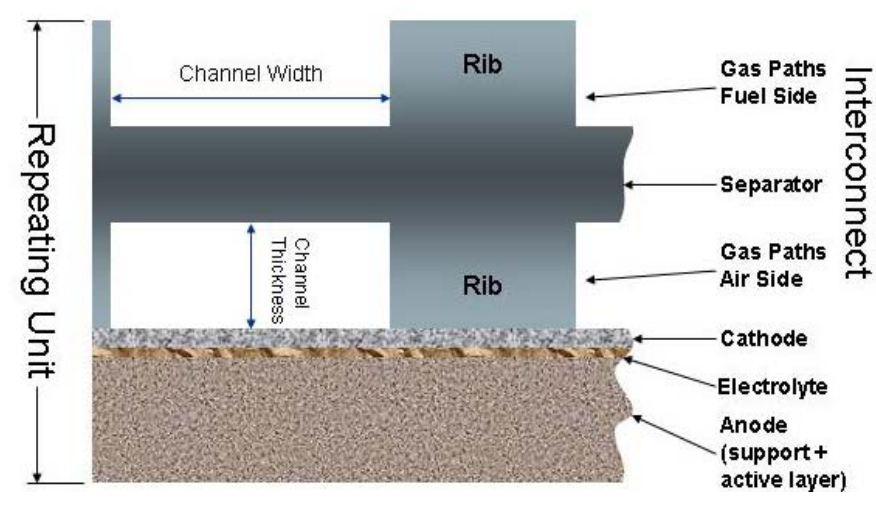

Figure 8.-Cell geometry for the baseline analysis. Table 1 Baseline system configuration data.

Unfortunately, as stated in reference [7] "Schematics of the cell design cannot be found in the public literature." The cell geometry assumed for this baseline analysis is shown in figure 8; specific dimensions and properties are given in [6]. Our SOFC mass model was based upon an anode supported cell concept along the lines of that shown in [7] for planar rectangular SOFC technology. Although electrode and electrolyte thickness values are available in the literature for specific concepts [7,17], exact interconnect dimensions have proven more elusive. We have relied upon the estimated values presented in [7].

\section{Sensitivity to Fuel Utilization, ASR, and Mission Duration}

Since the baseline configuration was more than four times the dry mass of the comparable Honeywell turbine APU, a sensitivity analysis was undertaken to explore options for mass reduction. Both fuel utilization and stack ASR were seen to have significant, interacting effects upon the system performance and mass. Area specific resistance was considered as a controlling variable for examining SOFC performance assumptions from current state-of-the-art toward aggressive performance goals. Utilization was considered as a control variable for examining the overall power split between the SOFC stacks and the single shaft turbomachinery generator. This power split can have a significant effect upon the system performance and mass by trading between the SOFC power system and the lighter (and less efficient) turbine-driven generator.

Evaluating specific energy over an assumed cruise mission length was one way to tie system efficiency and mass together. Specific energy incorporates the system dry mass together with the required fluid masses (jet fuel and water). A comparable figure for the conventional turbine APU system can be calculated for comparison purposes, if an assumed LHV efficiency is used. As mentioned in the introduction, current systems deliver electrical power from the main engine/generator system at approximately 42.5 percent of LHV of jet fuel.
Table 2 presents the sensitivity results. The mission lengths of three and ten hours were examined. Not surprisingly, the major system impact of improving stack performance (i.e., decreasing ASR) was to reduce the stack mass, which in turn reduced system mass substantially. Comparable specific energy figures for the Honeywell APU during the three and ten hour missions were 2.23 and $3.66 \mathrm{~kW}-\mathrm{h} / \mathrm{kg}$, respectively.

Fuel utilization had an interacting effect upon specific energy, depending upon the value of ASR and mission length. This can be best understood when recalling the total mass was composed of a fixed component (dry mass) and a variable component (fluid masses). In the limit of very short mission length, the total system mass is dominated by the dry-mass; consequently, reducing total mass is achieved by minimizing the dry mass. This can be achieved by reducing the fuel utilization in the SOFC stacks, thereby reducing the SOFC stack power in favor of more turbine power. In the limit of very long mission length, the dry mass is irrelevant and the system mass estimate is dominated by the fluid masses required; consequently, reducing total mass is achieved by reducing the required fluid masses (maximizing system efficiency). This can be achieved by increasing the fuel utilization within the efficient SOFC stacks. Between these two limiting cases, a trade between heavier, but more efficient, SOFC power and lighter, but less efficient, turbine power can be made, and it is dependant upon SOFC performance (i.e., ASR value) and the precise mission duration.

Figure 9 graphically depicts the short duration mission scenario discussed above. Notice that performance improved when the utilization was reduced. This is true for both the low and high ASR values. Figure 10 shows the long mission scenario discussed above, but only for the high-performance stack (ASR $\left.=0.2 \mathrm{ohm}-\mathrm{cm}^{2}\right)$. The lower performance SOFC $\left(\right.$ ASR $\left.=0.8 \mathrm{ohm}-\mathrm{cm}^{2}\right)$ exhibited the same behavior seen for relatively short duration missions.

Table 2.-Sensitivity analysis: specific energy $(\mathrm{kW}-\mathrm{h} / \mathrm{kg})$ as a function of SOFC fuel utilization and area specific resistance (ASR) for the 3-hr and 10-hr cruise missions.

\begin{tabular}{|c|c|c|c|c|c|c|}
\hline ASR & Util. & $\begin{array}{c}m_{\text {fuel }} \\
(\mathrm{kg} / \mathrm{s})\end{array}$ & $\begin{array}{c}m_{\text {H2O }} \\
(\mathrm{kg} / \mathrm{s})\end{array}$ & $\begin{array}{c}\text { Mass }_{\text {dry }} \\
(\mathrm{kg})\end{array}$ & $\begin{array}{c}E_{3} \\
(\mathrm{~kW}-\mathrm{h} / \mathrm{kg})\end{array}$ & $\begin{array}{c}E_{10} \\
(\mathrm{~kW}-\mathrm{h} / \mathrm{kg})\end{array}$ \\
\hline 0.2 & 0.4 & 0.0229 & 0.0203 & 592 & 1.248 & 2.052 \\
\hline 0.2 & 0.65 & 0.0186 & 0.0168 & 735 & 1.181 & 2.188 \\
\hline 0.2 & 0.9 & 0.0158 & 0.0144 & 913 & 1.066 & 2.202 \\
\hline 0.5 & 0.4 & 0.0228 & 0.0205 & 1112 & 0.836 & 1.648 \\
\hline 0.5 & 0.65 & 0.0185 & 0.0166 & 1457 & 0.719 & 1.616 \\
\hline 0.5 & 0.9 & 0.0158 & 0.0144 & 1839 & 0.610 & 1.504 \\
\hline 0.8 & 0.4 & 0.0228 & 0.0205 & 1624 & 0.631 & 1.383 \\
\hline 0.8 & 0.65 & 0.0186 & 0.0165 & 2160 & 0.520 & 1.285 \\
\hline 0.8 & 0.9 & 0.0158 & 0.0141 & 2774 & 0.426 & 1.142 \\
\hline
\end{tabular}




\section{Specific Energy (kW-h/kg): 3-hour mission}

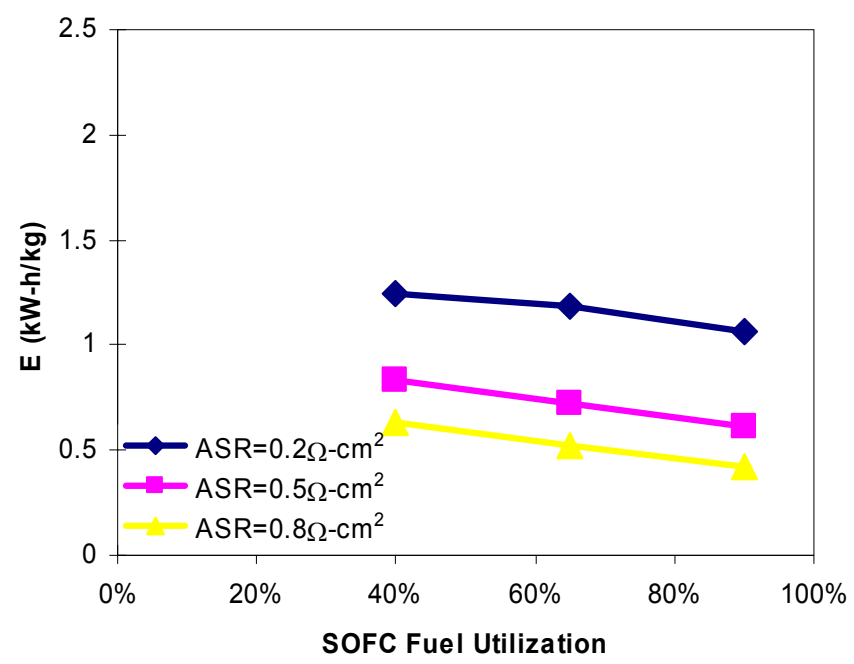

Figure 9.- Specific Energy for the three-hour cruise mission, as a function of SOFC fuel utilization at different ASR values.

\section{Specific Energy (kW-h/kg): 10-hour mission}

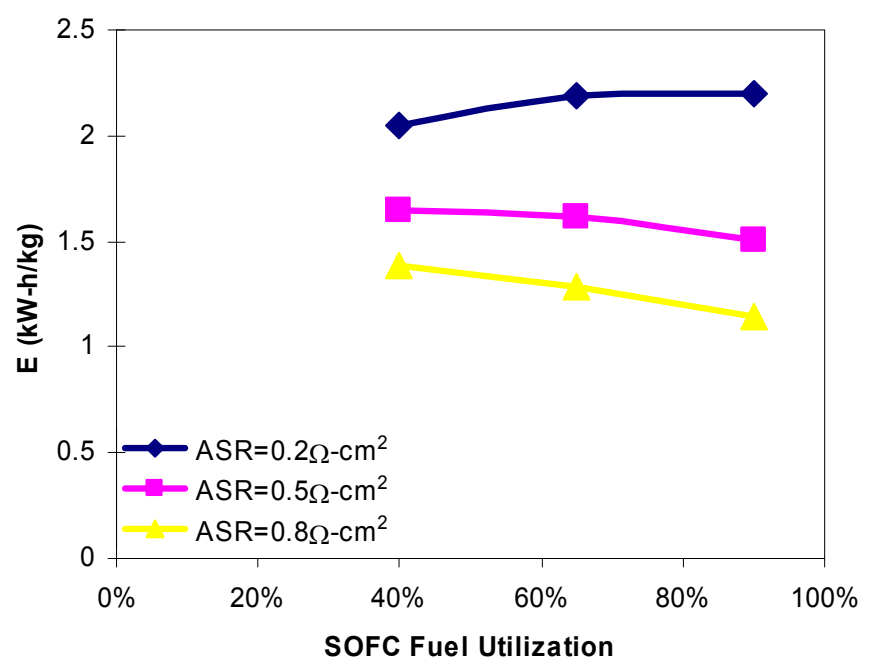

Figure 10.- Specific Energy for the ten-hour cruise mission, as a function of SOFC fuel utilization at different ASR values.
An analysis of the conventional power delivery system involving the main engine/generator system at 42.5 percent efficiency was quite revealing. Despite the apparent 20 percent efficiency penalty with respect to the SOFC/GT system, the specific energy of the turbine/generator always superseded the SOFC/GT system specific energy for all mission lengths using this thermodynamic power cycle. This counter-intuitive finding was due to the following result: variable (i.e., fluid) mass of the SOFC/GT was comprised of a fuel stream and water stream, while the conventional technology required only a fuel stream. The water was required for fuel reformation. The baseline thermodynamic cycle assumed that all the water needed for fuel reformation was gathered from an additional tank.

One well-established remedy for eliminating much of the required water supply involved recycling the anode effluent gas. Although some water would be required for startup situations, anode recycling can provide all of the required water supply for the reformation process. Due to the highly interactive components involved in the SOFC/GT power system, anode recycling will have a complex effect upon the performance and mass. A thorough analysis of this issue was beyond the scope of the present work.

\section{Sensitivity to Metallic Interconnect Technology}

Planar SOFC cell technologies have seen rapid progress over the last decade. According the US Department of Energy [1], "Over the past ten years, this technology has developed from a scientific concept to cell technologies that can achieve $1.8 \mathrm{~W} / \mathrm{cm}^{2}$ under idealized laboratory conditions, and stacks that can achieve initial power densities of 300 to $500 \mathrm{~mW} / \mathrm{cm}^{2}$." The Department of Energy Solid State Energy Conversion Alliance (SECA) program has enabled progress on both fundamental science and SOFC stack development. This has contributed to the proliferation of cell and stack concepts in the literature. It is not surprising that certain concepts show more promise of achieving the high specific energy requirements demanded of transportation sector in general and aerospace sector in particular.

Cell designs that reduce the mass of the interconnect layer would help to improve the specific energy figures discussed above. Replacing the metallic layer with a ceramic layer is one approach that has been pursued by several industrial partners. Other approaches result from the realization that the interconnect thickness of figure 8 is dictated by the gas path geometry as opposed to electrochemical considerations. Designs that form the gas paths directly in the anode support layer can utilize a thin, planar interconnect. One specific concept is the metallic foil interconnect outlined in [7]. This has several interesting benefits: the repeating unit thickness can be reduced, the repeating unit mass can be reduced, and the non-planar electrolyte surface is increased per repeating unit volume. Figure 11 shows a scaled comparison of the two concepts; estimated repeating unit dimensions can be found from [7]. 


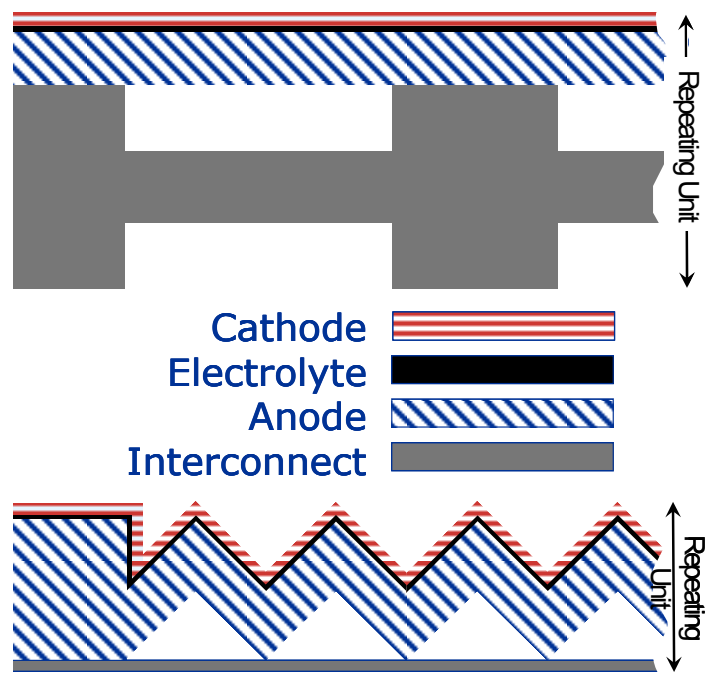

Figure 11.-Cell geometry for planar, anode supported Solid Oxide Fuel Cells: (a) gas channels are formed in the metallic interconnect layer, and (b) gas channels are formed in the porous anode support layer. Note that the electrode and electrolyte layers are similar between the two configurations; an important difference exists in the mass of the metallic interconnect layer.

When we swap in the new cell geometry for the baseline case analysis, the improvement was dramatic. The change in repeating unit mass breakdown is shown in figure 12 . The SOFC stack mass was reduced from 1097 to $441 \mathrm{~kg}$. The system mass breakdown has changed accordingly, as shown in figure 13. Clearly, technologies directed at dematerializing the metallic interconnect layer hold great potential for the transportation sector in general, and aerospace in particular.

\section{Conclusions}

A notional $440 \mathrm{~kW}$ SOFC/GT hybrid APU has been examined for use in the timeframe of 2015. The primary interest behind this new concept for aircraft auxiliary power was the goal of NOx reduction. SOFC/GT systems with catalytic combustion can eliminate NOx emissions from this process. The difficulty lies in the additional mass required for the energy conversion device, and the additional water required for fuel reformation.

Systems level simulations were used to conduct this study and component performance models were presented herein. A baseline configuration was presented that utilized planar, anode-supported SOFC technology along with single-shaft turbomachinery, combined in a single-pass thermodynamic cycle. The notional baseline system operated at 62.6 percent efficiency (LHV) and had a dry mass of $1396 \mathrm{~kg}$. The overall system mass was dominated by the SOFC stack mass, which in turn was dominated by the metallic

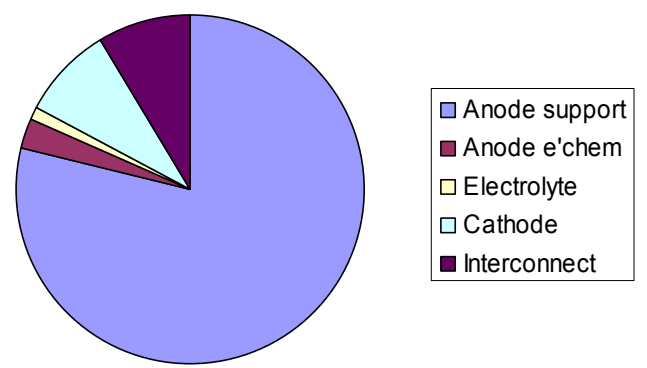

Figure 12.- Repeating unit mass breakdown of the planar, anode supported SOFC using a corrugated support anode (total $269 \mathrm{~g}$ ).

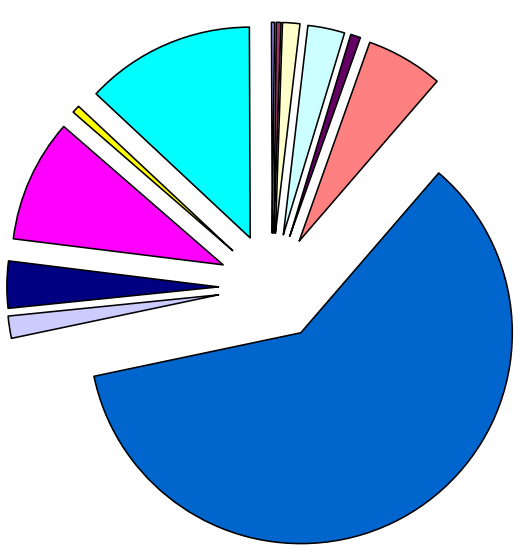

Figure 13.-SOFC/GT hybrid power APU system with metallic foil interconnect: mass breakdown by component. The total system mass is $720 \mathrm{~kg}$.

interconnect mass. The baseline configuration was determined to be four times as heavy as a comparable allturbine APU engine.

We presented the results of a sensitivity analysis involving the assumed SOFC technology performance level (ASR) and the fuel utilization within the SOFC stacks for two cruise missions. Area specific resistance had a strong influence upon overall system mass. Fuel utilization had a strong influence upon determining the portion of the total power developed from the SOFC stacks. Mission duration had an interacting effect upon the above two variables, and must be considered for further optimization studies.

Different SOFC stack assemblies can have a dramatic effect upon the total system mass. Corrugated flow channels, formed directly into the support anode layer, offer a considerable improvement in specific energy. The repeating unit is less massive, and the corrugated topology of the electrolyte offers a substantial increase in active area per unit volume of the repeating unit. Technologies directed at dematerializing the metallic interconnect layer hold great potential for the transportation sector in general, and aerospace in particular. 
Finally, the SOFC/GT power system demanded a considerable amount of additional water to be delivered to the fuel reformer to avoid graphite formation. For the simple cycle results presented, the system specific power of the SOFC/GT was not able to out perform the main engine/generator combination that is currently employed for auxiliary electric power during cruise missions. This was due to the increased dry mass estimate and the increased fluids mass estimate. Cycle modifications, especially anode effluent recycling, offer promise for improving this situation by reducing the additional water required for operation.

\section{References}

[1] Fuel Cell Handbook, $7^{\text {th }}$ Edition, (2004), EG\&G Technical Services, Inc., Under U.S. Dept. of Energy Contract DE-AM26-99FT40575, National Energy Technology Laboratory, Morgantown, WV, USA.

[2] Veyo, S., Litzinger, K., Vora, S., and Lundberg, W. (2002). "Status of Pressurized SOFC/Gas Turbine Power System Development at Siemens Westinghouse", ASME GT-2002-30670, ASME Turbo Expo 2002, Amsterdam, The Netherlands.

[3] Freeh, J.E., Pratt, J.W., Brouwer, J., (2004) "Development of a Solid-Oxide Fuel Cell/Gas Turbine Hybrid System Model for Aerospace Applications," GT2004-53616, ASME Turbo Expo 2004, Vienna, Austria.

[4] Daggett, D., Freeh, J. Balan, C., and Birmingham, D.; (2003) "Fuel Cell APU for Commerical Aircraft," 2003 Fuel Cell Seminar Abstracts, Miami, FL, USA.

[5] Daggett, D., Eelman, S., and Kristiansson, G., (2003) "Fuel Cell APU for Commercial Aircraft," AIAA-20032660, AIAA International Air and Space Symposium and Exposition: The Next 100 Years, Dayton, OH, USA.

[6] Tornabene, R., Wang, X.-Y., Steffen, C.J. Jr., Freeh, J.E., (2005) "Development of Parametric Mass and Volume Models for an Aerospace SOFC/Gas Turbine Hybrid System," ASME GT-2005-68334, ASME Turbo Expo 2005, Reno, NV, USA (Under review).
[7] Assessment of Solid Oxide Fuel Cell Technology: Comparison of Alternative Design Approaches, (2000) EPRIsolutions, Palo Alto, CA, USA: 1003966.

[8] Petroleum Quality Information System: Fuels Data Report, (1999) Defense Energy Support Center, Ft. Belvoir, VA, USA.

[9] Petroleum Quality Information System: Fuels Data Report, (2000) Defense Energy Support Center, Ft. Belvoir, VA, USA.

[10] Petroleum Quality Information System: Fuels Data Report, (2001) Defense Energy Support Center, Ft. Belvoir, $\mathrm{VA}$, USA.

[11] CRC Report No. 530. (1984) Handbook of Aviation Fuel Properties. Atlanta, GA, USA: Coordinating Research Council.

[12] Hadaller, O.J., Roseburg, C.M., and Monsrud, M.E. (2000) "The Impact on Commercial Aviation from Reducing the Sulfur Content in Jet Fuel," NASA Contractor Report NASI-20267.

[13] Hartvigsen, J., Khandkar, A., and Elangovan, S. (1999) "Development of an SOFC Stack Performance Map for Natural Gas Operation," Proceedings of the Electrochemical Society PV 99-19, Honolulu, HI, USA.

[14] Claus, R.W., McBride, B.J., and Foster, R. (2005) "Application of a Chemical Equilibrium Analysis to In-Situ Lunar Resource Utilization," 1st AIAA Space Exploration Conference: Continuing the Voyage of Discovery, Orlando, FL

${ }^{15}$ High Temperature Solid Oxide Fuel Cells: Fundamentals, Design, and Applications, (2003), Singhal, S.C., and Kendall, K., Editors, ISBN: 1856173879., Elsevier Ltd.

[16] Glassman, A.J., (1995) "Design geometry and design/off-design performance computer codes for compressors and turbines; Final Report", NASA-CR198433.

[17] Handbook of Fuel Cells: Fundamentals, Technology, Applications, (2003) Vielstich, W., Lamm, A. and Gasteiger H., Editors, ISBN: 0-471-49926-9. 
Public reporting burden for this collection of information is estimated to average 1 hour per response, including the time for reviewing instructions, searching existing data sources, gathering and maintaining the data needed, and completing and reviewing the collection of information. Send comments regarding this burden estimate or any other aspect of this collection of information, including suggestions for reducing this burden, to Washington Headquarters Services, Directorate for Information Operations and Reports, 1215 Jefferson Davis Highway, Suite 1204, Arlington, VA 22202-4302, and to the Office of Management and Budget, Paperwork Reduction Project (0704-0188), Washington, DC 20503.

\begin{tabular}{|l|l|l}
\hline 1. AGENCY USE ONLY (Leave blank) & $\begin{array}{c}\text { 2. REPORT DATE } \\
\text { April } 2005\end{array}$ & $\begin{array}{r}\text { 3. REPORT TYPE AND DATES COVERED } \\
\text { Technical Memorandum }\end{array}$ \\
\hline
\end{tabular}

\section{TITLE AND SUBTITLE}

Solid Oxide Fuel Cell/Gas Turbine Hybrid Cycle Technology for

Auxiliary Aerospace Power

6. AUTHOR(S)

Christopher J. Steffen, Jr., Joshua E. Freeh, and Louis M. Larosiliere

\section{FUNDING NUMBERS}

WBS-22-708-02-03

\section{PERFORMING ORGANIZATION NAME(S) AND ADDRESS(ES)}

National Aeronautics and Space Administration

John H. Glenn Research Center at Lewis Field

Cleveland, Ohio 44135-3191
8. PERFORMING ORGANIZATION REPORT NUMBER

E-15053

\section{SPONSORING/MONITORING AGENCY NAME(S) AND ADDRESS(ES)}

National Aeronautics and Space Administration

Washington, DC 20546-0001

10. SPONSORING/MONITORING AGENCY REPORT NUMBER

NASA TM-2005-213586 GT2005-68619

\section{SUPPLEMENTARY NOTES}

Prepared for the Turbo Expo 2005 sponsored by the American Society of Mechanical Engineers, Reno, Nevada, June 6-9, 2005. Responsible person, Christopher J. Steffen, Jr., organization code RTS, 216-433-8508.

12a. DISTRIBUTION/AVAILABILITY STATEMENT

12b. DISTRIBUTION CODE

Unclassified - Unlimited

Subject Category: 07

Available electronically at http://gltrs.grc.nasa.gov

This publication is available from the NASA Center for AeroSpace Information, 301-621-0390.

13. ABSTRACT (Maximum 200 words)

A notional $440 \mathrm{~kW}$ auxiliary power unit has been developed for 300 passenger commercial transport aircraft in 2015AD. A hybrid engine using solid-oxide fuel cell stacks and a gas turbine bottoming cycle has been considered. Steady-state performance analysis during cruise operation has been presented. Trades between performance efficiency and system mass were conducted with system specific energy as the discriminator. Fuel cell performance was examined with an area specific resistance. The ratio of fuel cell versus turbine power was explored through variable fuel utilization. Area specific resistance, fuel utilization, and mission length had interacting effects upon system specific energy. During cruise operation, the simple cycle fuel cell/gas turbine hybrid was not able to outperform current turbine-driven generators for system specific energy, despite a significant improvement in system efficiency. This was due in part to the increased mass of the hybrid engine, and the increased water flow required for on-board fuel reformation. Two planar, anode-supported cell design concepts were considered. Designs that seek to minimize the metallic interconnect layer mass were seen to have a large effect upon the system mass estimates.

\section{SUBJECT TERMS}

Thermodynamic cycles; Auxiliary power unit; Solid oxide fuel cell; SOFC/GT hybrid; Aerospace power; Specific energy

\begin{tabular}{|c|c|c|}
\hline $\begin{array}{c}\text { 17. SECURITY CLASSIFICATION } \\
\text { OF REPORT } \\
\text { Unclassified }\end{array}$ & $\begin{array}{c}\text { 18. SECURITY CLASSIFICATION } \\
\text { OF THIS PAGE } \\
\text { Unclassified }\end{array}$ & $\begin{array}{c}\text { 19. SECURITY CLASSIFICATION } \\
\text { OF ABSTRACT } \\
\text { Unclassified }\end{array}$ \\
\hline
\end{tabular}

15. NUMBER OF PAGES

15

16. PRICE CODE

\section{LIMITATION OF ABSTRACT}



